Revue bibliographique pour le domaine irano-aryen

\title{
Christelle Jullien. « Découverte d'un martyr perse dans un légendier latin médieval »
}

\section{Marie-Joseph Pierre}

\section{Q OpenEdition}

1 Journals

\section{Édition électronique}

URL : http://journals.openedition.org/abstractairanica/42760

DOI : 10.4000/abstractairanica.42760

ISBN : 1961-960X

ISSN : 1961-960X

Éditeur :

CNRS (UMR 7528 Mondes iraniens et indiens), Éditions de l'IFRI

Référence électronique

Marie-Joseph Pierre, « Christelle Jullien. « Découverte d'un martyr perse dans un légendier latin médieval » », Abstracta Iranica [En ligne], Volume 37-38-39 | 2018, document 10, mis en ligne le 10 mars 2018, consulté le 27 septembre 2020. URL : http://journals.openedition.org/abstractairanica/ 42760 ; DOI : https://doi.org/10.4000/abstractairanica.42760

Ce document a été généré automatiquement le 27 septembre 2020.

Tous droits réservés 


\title{
Christelle Jullien. « Découverte d'un martyr perse dans un légendier latin médieval »
}

\author{
Marie-Joseph Pierre
}

\section{RÉFÉRENCE}

Christelle Jullien. « Découverte d'un martyr perse dans un légendier latin médieval », Analecta Bollandiana 134, 2016, p. 5-19.

1 La première partie du Légendier de Moissac (ms. latin BnF 17002) a conservé de façon totalement inattendue la Passion d'un chrétien perse mort martyr, décapité en 422 à Séleucie-Ctésiphon, capitale de l'empire sassanide, du nom de Vamnes (BHL 8499). Cette découverte est d'autant plus intéressante que ce Perse est totalement inconnu des traditions chrétiennes orientales. Cet unicus révèle un authentique récit martyrologique syriaque décelable en filigrane du texte latin par une convergence d'éléments probants d'une grande valeur historique. Le milieu grec byzantin a sans doute servi de canal de transmission vers l'Occident latin.

\section{AUTEURS}

MARIE-JOSEPH PIERRE

Directrice d'Études honoraire, EPHE 